\title{
Can the botanical azadirachtin replace phased-out soil insecticides in suppressing the soil insect pest Diabrotica virgifera virgifera?
}

\author{
Stefan Toepfer ${ }^{1,2^{*}}$ (D), Szabolcs Toth ${ }^{1,2}$ and Mark Szalai ${ }^{2}$ (D)
}

\begin{abstract}
Background: Due to recent bans on the use of several soil insecticides and insecticidal seed coatings, soil-dwelling insect pests are increasingly difficult to manage. One example is the western corn rootworm (Diabrotica virgifera virgifera, Coleoptera: Chrysomelidae), a serious root-feeder of maize (Zea mays). We investigated whether the less problematic botanical azadirachtin, widely used against above-ground insects, could become an option for the control of this soil insect pest.

Methods: Artificial diet-based bioassays were implemented under standard laboratory conditions to establish dose response curves for the pest larvae. Then, potted-plant experiments were implemented in greenhouse to assess feasibility and efficacy of a novel granular formulation of azadirachtin under more natural conditions and in relation to standard insecticides.

Results: Bioassays in three repetitions revealed a 3-day $\mathrm{LD}_{50}$ of $22.3 \mu \mathrm{g}$ azadirachtin/ml which corresponded to $0.45 \mu \mathrm{g} /$ neonate of $D$. v. virgifera and a 5 -day $\mathrm{LD}_{50}$ of $19.3 \mu \mathrm{g} / \mathrm{ml}$ or $0.39 \mu \mathrm{g} /$ first to second instar larva. No sublethal effects were observed. The three greenhouse experiments revealed that the currently proposed standard dose of a granular formulation of $38 \mathrm{~g}$ azadirachtin/hectare for in-furrow application at sowing is not enough to control D. $v$. virgifera or to prevent root damage. At 10x standard-dose total pest control was achieved as well as the prevention of most root damage. This was better than the efficacy achieved by cypermethrin-based granules and comparable to tefluthrin-granules, or thiamethoxam seed coatings. The $\mathrm{ED}_{50}$ for suppressing larval populations were estimated at $92 \mathrm{~g}$ azadirachtin/ha, for preventing heavy root damage $52 \mathrm{~g} / \mathrm{ha}$ and for preventing general root damage $220 \mathrm{~g} / \mathrm{ha}$.

Conclusions: There seems clear potential for the development of neem-based botanical soil insecticides for arable crops such as maize. They might become, if doses are increased and more soil insecticides phased out, a promising, safer solution as part of the integrated pest management toolkit against soil insects.
\end{abstract}

Keywords: Integrated pest management, Western corn rootworm, Azadirachtin, Zea mays, Biopesticide, Soil insecticide, Biological control

\section{Introduction}

Corn rootworms are, next to wireworms, grubs and cutworms, serious soil-dwelling insect pests of maize (Zea mays). One of the rootworms, the western corn

\footnotetext{
*Correspondence: s.toepfer@cabi.org

${ }^{1}$ CABI, Rue des Grillons 1, CH 2800 Delémont, Switzerland

Full list of author information is available at the end of the article
}

rootworm (Diabrotica virgifera virgifera, Coleoptera: Chrysomelidae) is one of the most problematic (Krysan and Miller 1986). Its three larval instars feed almost exclusively on the roots of maize, which becomes apparent when plants lodge (Chiang 1973). Diabrotica v. virgifera causes yield losses to large maize production areas of the USA and southern Canada (Kim and Sappington 2005) as well as in Central Europe (Miller et al. 2005). 
Affected growers attempt to manage the pest mainly through rotating their fields, thereby interrupting the life cycle of $D$. v. virgifera. Many growers apply granular or fluid soil insecticides, mainly pyrethroids or organophosphates, or use neonicotinoid-coated maize seeds to target the root feeding larvae. North American growers also use transgenic maize expressing different Bacillus thuringiensis proteins which are toxic to rootworms (Levine and Oloumi-Sadeghi 1991; Domínguez-Arrizabalaga et al. 2020), but their efficacies under field conditions are variable (Clair et al. 2020; Gassmann et al. 2020). Additionally, broad-spectrum foliar insecticides are occasionally sprayed against the adults using high clearance spraying machinery (Rozen and Ester 2010). Foliar insecticides are often broad spectrum and knock-down contact-pesticides with considerable non-target effects. Also, many soil insecticides and seed coatings are problematic due to their human toxicity and/or serious non-target or other environmental effects.

This has resulted in public concerns and in a ban on the use of neonicotinoid seed-coatings in field crops (Georgiadis et al. 2011), and restrictions in the use chlorpyrifos- and tefluthrin-based soil insecticides in many countries. Only few countries remain, that still have such ingredients on the soil pesticide market, such as the USA. In Hungary, tefluthrin is only registered under special emergency registration. However, tefluthrin will definitely disappear from the European pesticide market (European-Commission 2011) and likely from the entire global market due to its high acute toxicity (World Health Organization 2009). Therefore, options for growers to control $D$. v. virgifera, and also other soil insect pests such as wireworms, grubs and cutworms will be limited, particularly in Europe. Novel pest management solutions and agents are urgently needed, particularly less environmentally-disruptive ones.

For example, neem preparations with their active ingredients of different azadirachtins are widely-used botanical insecticides (Saxena 1989; Scmutterer 1995; Dougoud et al. 2019). Although its modes of action are still somewhat uncertain, they are known to have broad spectrum insecticidal activity as well as some nematocidal, isopodicidal, fungicidal and plant promoter activity (CRC 1989; Doshi et al. 2018, 2020). There are numerous products available in most world regions, mainly against above-ground, soft-bodied insect pests (Dougoud et al. 2019). In some regions, growers also prepare self-made homebrews from leaves or seeds of the tree Azadirachta indica, which is of south Asian origin but nowadays widely distributed in the tropics and sub-tropics of many regions (Dougoud et al. 2019). The advantage of neem is that it has a low acute or chronic toxicity to humans and breaks down relatively quickly in the environment (Boeke et al. 2004). Another advantage is that neem is systemic, translaminar as well as of contact mode of activity (Stark and Rangus 1994; Dougoud et al. 2019), allowing its diverse usage. It can directly cause mortality to insects, can inhibit growth and moulting, and even can cause chronic effects such as on insect fertility (Ladd Jr et al. 1984; Al-Sharook et al. 1991; Stark and Rangus 1994; Mehaoua et al. 2013; Merabti et al. 2017).

Astonishingly, there are still limited studies and limited use of neem products against below-ground insect pests (Bhagat 2005). This is surprising because neem leaves, grinded seeds or leftovers from seed processing are occasionally used as a soil amendment against plant parasitic nematodes (Dougoud et al. 2019) as well as a biofertilizer, even in maize (Vageesh et al. 2016). Neem seed extracts also has some fungicidal properties when used as coating of maize seeds (Sowley et al. 2017). Consequently, there exist some experience for in-soil applications of neem, such as leaves or commercial granules (Balaji 2014). Nevertheless, only few products are available for soil application, and knowledge on their effects against soil insects is limited due to their concealment below-ground in or on the roots of crops.

This is particularly true for rootworms (Diabroticina), several of them, as stated above, being serious root-feeding pests of maize. Azadirachtin is known to be toxic to rootworm larvae, such as against $D$. speciosa (Boiça Júnior et al. 2017) or the here-studied D. v. virgifera (Xie et al. 1991), and repellent to larvae of cucumber beetles such as Diabrotica undecimpunctata howardi (Landis and Gould 1989) or to adults of the closely related Acalymma vittatum (Reed et al. 1982). However, further experimentation on the use of azadirachtin against rootworms seem scarce. Only Estes et al.(2018) attempted to examine liquid and granular formulations of neem against $D$. v. virgifera larvae in Illinois, USA, but with inconclusive results. There seems a knowledge gap on how to effectively use neem against rootworms or other soil insect pests, a gap we try to close with the here-presented study.

We aimed at better understanding the pest control potential of azadirachtin using a novel granular neembased soil insecticide. First, bioassays were conducted to establish the $\mathrm{LD}_{50}$ of azadirachtin on the neonates of $D$. v. virgifera. Second, the suggested standard dose of neem granules was compared with lower and higher dosages in relation to standard insecticides in potted-maize plant trials under semi-natural conditions. This set of experimental steps was hoped to allow conclusions on the efficacy and potential feasibility of neem-based granule applications for corn rootworm control. Ultimately, this would help to diversify the currently limited integrated 
pest management toolbox against rootworms and potentially other soil insect pests.

\section{Material and methods} Target pest Diabrotica v. virgifera

Diabrotica virgifera virgifera LeConte (Coleoptera: Chrysomelidae, western corn rootworm, EPPO code DIABVI) were mass-reared following procedures of George and Ortman (1965), Branson et al. (1975) and Singh and Moore (1999). A non-diapause colony (USDA ARS, Bookings, USA) was used to infest artificial dietbased bioassay with neonates and potted-maize plants in greenhouse experiments with ready-to-hatch eggs (see procedures below). The population is considered susceptible to most insecticides or novel agents as it had not been exposed to any of those, and therefore resistance is considered unlikely (Wright et al. 2000; Magalhaes et al. 2007).

\section{Test agents}

An azadirachtin-based granular soil insecticide was tested against $D$. v. virgifera larvae in comparison to a set of commonly used contact and/or systemic insecticides (positive controls) as well as to untreated controls (Tables 1, 2).

In artificial-diet based bioassays against neonates of D. v. virgifera in the laboratory, azadirachtin-granules were dissolved in water and $20 \mu \mathrm{l}$ applied/well/larva (see details below). Those dissolved azadirachtin granules were compared with a commercial fluid azadirachtin formulations and the insecticides tefluthrin, cypermethrin, imidacloprid as well as with untreated control (Table 1).

In potted-maize experiments under greenhouse conditions, azadirachtin-granules were manually applied when the maize seeds were placed into a sowing furrow across the pots (see details below). The azadirachtinbased granular soil insecticide was compared with the soil insecticides tefluthrin and cypermethrin and to thiamethoxam-coated seeds as well as with untreated infested and un-infested control (Table 2).

Azadirachtin was tested as per Tables 1 and 2. The main test product was a granule formulation provided by Coromandel International Ltd, India (NeemAzal ${ }^{\mathrm{TM}}$ $0.15 \mathrm{G}$ similar to Avana ${ }^{\mathrm{TM}}$ by Parry America). It contained $0.165 \%$ azadirachtin (mainly A with some B, chromatogram-verified, batch 2001-10) as well as $0.35 \%$ other neem compounds (Aza-F, Aza-H, Aza-I, salanin,

Table 1 Treatment characteristics in artificial diet-based bioassay against neonates of Diabrotica v. virgifera under standardised semisterile laboratory conditions

\begin{tabular}{|c|c|c|c|c|c|}
\hline Treatment & Formulation & Dose/ml (a.i.) & Dose $/ \mathrm{cm}^{2}$ (a.i.) & $\begin{array}{l}\text { Dose } / 20 \mu \mathrm{l} / 0.34 \mathrm{~cm}^{2} \\
\text { well/larva (a.i.) }\end{array}$ & $\begin{array}{l}\text { Experiment number (\# } \\
\text { plates; \# wells) }\end{array}$ \\
\hline \multicolumn{6}{|l|}{ Test agent } \\
\hline \multirow[t]{4}{*}{ Azadirachtin $0.15 \%($ Neem Azaal 0.15G) } & Granule & $0.067 \mathrm{mg}(0.1 \mu \mathrm{g})$ & $0.0038 \mathrm{mg}(0.006 \mu \mathrm{g})$ & $0.0013 \mathrm{mg}(0.002 \mu \mathrm{g})$ & $3(6 ; 48)$ \\
\hline & & $0.67 \mathrm{mg}(1 \mu \mathrm{g})$ & $0.038 \mathrm{mg}(0.06 \mu \mathrm{g})$ & $0.013 \mathrm{mg}(0.02 \mu \mathrm{g})$ & $3(6 ; 48)$ \\
\hline & & $6.7 \mathrm{mg}(10 \mu \mathrm{g})$ & $0.38 \mathrm{mg}(0.6 \mu \mathrm{g})$ & $0.13 \mathrm{mg}(0.2 \mu \mathrm{g})$ & $3(6 ; 48)$ \\
\hline & & $66.7 \mathrm{mg}(100 \mu \mathrm{g})$ & $38 \mathrm{mg}(6 \mu \mathrm{g})$ & 1.33 mg (2 $\mu \mathrm{g})$ & $3(6 ; 48)$ \\
\hline \multirow[t]{9}{*}{ Azadirachtin 1\% (NeemAzal-T/S 10EC) } & Fluid & $0.01 \mu \mathrm{l}(0.1 \mu \mathrm{g})$ & $0.0006 \mu \mathrm{l}(0.006 \mu \mathrm{g})$ & $0.0002 \mu \mathrm{l}(0.002 \mu \mathrm{g})$ & $3(6 ; 48)$ \\
\hline & & $0.1 \mu \mathrm{l}(1 \mu \mathrm{g})$ & $0.006 \mu \mathrm{l}(0.06 \mu \mathrm{g})$ & $0.002 \mu \mathrm{l}(0.02 \mu \mathrm{g})$ & $3(6 ; 48)$ \\
\hline & & $1 \mu \mathrm{l}(10 \mu \mathrm{g})$ & $0.06 \mu \mathrm{l}(0.6 \mu \mathrm{g})$ & $0.02 \mu \mathrm{l}(0.2 \mu \mathrm{g})$ & $1(3 ; 24), 2(6 ; 48), 3(6 ; 48)$ \\
\hline & & $3 \mu \mathrm{l}(30 \mu \mathrm{g})$ & $0.18 \mu \mathrm{l}(1.8 \mu \mathrm{g})$ & $0.06 \mu \mathrm{l}(0.6 \mu \mathrm{g})$ & $1(3 ; 24)$ \\
\hline & & $5 \mu \mathrm{l}(50 \mu \mathrm{g})$ & $0.3 \mu \mathrm{l}(3 \mu \mathrm{g})$ & $0.1 \mu \mathrm{l}(1 \mu \mathrm{g})$ & $1(3 ; 24)$ \\
\hline & & $10 \mu \mathrm{l}(100 \mu \mathrm{g})$ & $0.6 \mu \mathrm{l}(6 \mu \mathrm{g})$ & $0.2 \mu \mathrm{l}(2 \mu \mathrm{g})$ & $1(3 ; 24), 2(6 ; 48), 3(6 ; 48)$ \\
\hline & & $100 \mu \mathrm{l}(1000 \mu \mathrm{g})$ & $6 \mu \mathrm{l}(60 \mu \mathrm{g})$ & $2 \mu \mathrm{l}(20 \mu \mathrm{g})$ & $1(3 ; 24), 2(6 ; 48)$ \\
\hline & & $500 \mu \mathrm{l}(5000 \mu \mathrm{g})$ & $30 \mu \mathrm{l}(300 \mu \mathrm{g})$ & $10 \mu \mathrm{l}(100 \mu \mathrm{g})$ & $2(6 ; 48)$ \\
\hline & & $1000 \mu \mathrm{l}(10,000 \mu \mathrm{g})$ & $60 \mu \mathrm{l}(600 \mu \mathrm{g})$ & $20 \mu \mathrm{l}(200 \mu \mathrm{g})$ & $2(6 ; 48)$ \\
\hline \multicolumn{6}{|l|}{ Positive controls } \\
\hline Imidacloprid 20\% (Confidor 200 SL) & Fluid & $0.01 \mu \mathrm{l}(2 \mu \mathrm{g})$ & $0.0006 \mu \mathrm{l}(0.12 \mu \mathrm{g})$ & $0.0002 \mu \mathrm{l}(0.04 \mu \mathrm{g})$ & $1(3 ; 24), 2(6 ; 48), 3(6 ; 48)$ \\
\hline Cypermethrin 0.8\% (Belem 0.8 MG) & Micro granule & $12.5 \mathrm{mg}(100 \mu \mathrm{g})$ & $0.73 \mathrm{mg}(5.9 \mu \mathrm{g})$ & $0.25 \mathrm{mg}(2 \mu \mathrm{g})$ & $3(6 ; 48)$ \\
\hline Tefluthrin 1.5\% (Force 1.5G) & Fine granule & $6.7 \mathrm{mg}(100 \mu \mathrm{g})$ & $0.38 \mathrm{mg}(5.9 \mu \mathrm{g})$ & $0.13 \mathrm{mg}(2 \mu \mathrm{g})$ & $3(6 ; 48)$ \\
\hline \multicolumn{6}{|l|}{ Negative controls } \\
\hline Untreated-infested & - & - & - & - & $1(3 ; 24), 2(6 ; 48), 3(6 ; 48)$ \\
\hline Untreated un-infested & - & - & - & - & $1(3 ; 24), 2(6 ; 48), 3(6 ; 48)$ \\
\hline
\end{tabular}

Each diet-filled well infested with one neonate larva

${ }^{\text {a }}$ Similar to Avana ${ }^{\mathrm{TM}}$ by Parry America 
Table 2 Treatment characteristics in potted-maize plant experiments against larvae of Diabrotica $v$. virgifera under greenhouse conditions

\begin{tabular}{|c|c|c|c|c|c|c|}
\hline Treatment & Formulation & Dose/ha (a.i.) & $\begin{array}{l}\text { Dose/meter furrow } \\
\text { (a.i.) }\end{array}$ & $\begin{array}{l}\text { Dose } / 10 \mathrm{~cm} \\
\text { furrow/plant/pot } \\
\text { (a.i.) }\end{array}$ & Dose $/ \mathrm{cm}^{2}$ (a.i.) & $\begin{array}{l}\text { Experiment number } \\
\text { (\# blocks; \# plants) }\end{array}$ \\
\hline \multicolumn{7}{|l|}{ Test agent } \\
\hline \multirow{2}{*}{$\begin{array}{l}\text { Azadirachtin 0.15\% } \\
\text { (Neem Azaal } \\
0.15 \mathrm{G})^{\mathrm{a}}\end{array}$} & \multirow[t]{5}{*}{ Granule } & 18 kg (27 g) & $1.3 \mathrm{~g}(2 \mathrm{mg})$ & 130 mg (0.2 mg) & $26 \mathrm{mg}(40 \mu \mathrm{g})$ & $3(3 ; 15)$ \\
\hline & & $25 \mathrm{~kg}(38 \mathrm{~g})^{\mathrm{s}}$ & $1.9 \mathrm{~g}(2.8 \mathrm{mg})$ & 190 mg (0.28 mg) & 38 mg $(56 \mu g)$ & $\begin{array}{l}1(3 ; 15), 2(4 ; 20), 3 \\
\quad(3 ; 15)\end{array}$ \\
\hline \multirow[t]{3}{*}{ (limoid) } & & 135 kg (200 g) & $10.2 \mathrm{~g}(15 \mathrm{mg})$ & 1020 mg (1.5 mg) & 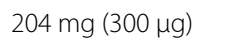 & $3(3 ; 15)$ \\
\hline & & 250 kg (370 g) & $19 \mathrm{~g}(28 \mathrm{mg})$ & 1900 mg (2.8 mg) & 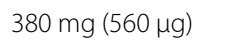 & $3(3 ; 15)$ \\
\hline & & 2500 kg (3700 g) & 190 g (280 mg) & 19,000 mg (28 mg) & 3800 mg $(5600 \mu \mathrm{g})$ & $3(3 ; 15)$ \\
\hline \multicolumn{7}{|l|}{ Positive controls } \\
\hline \multirow{2}{*}{$\begin{array}{l}\text { Cypermethrin 0.8\% } \\
\text { (Belem 0.8 MG) } \\
\text { (pyrethroid) }\end{array}$} & \multirow[t]{2}{*}{ Micro granule } & $12 \mathrm{~kg}(96 \mathrm{~g})^{\mathrm{s}}$ & $0.9 \mathrm{~g}(7.2 \mathrm{mg})$ & 90 mg (0.72 mg) & $18 \mathrm{mg}(0.14 \mu \mathrm{g})$ & $1(3 ; 15), 2(4 ; 20)$ \\
\hline & & $25 \mathrm{~kg}(200 \mathrm{~g})$ & $1.9 \mathrm{~g}(15 \mathrm{mg})$ & 188 mg (1.5 mg) & $38 \mathrm{mg}(0.3 \mu \mathrm{g})$ & $3(3 ; 15)$ \\
\hline $\begin{array}{l}\text { Tefluthrin 1.5\% } \\
\text { (Force 1.5G) } \\
\text { (pyrethroid) }\end{array}$ & Fine granule & $13.3 \mathrm{~kg}(200 \mathrm{~g})^{\mathrm{s}}$ & $1 \mathrm{~g}(15 \mathrm{mg})$ & 100 mg (1.5 mg) & 20 mg $(0.3 \mu \mathrm{g})$ & $\begin{array}{l}1(3 ; 15), 2(4 ; 20), 3 \\
\quad(3 ; 15)\end{array}$ \\
\hline $\begin{array}{l}\text { Thiamethoxam } \\
\text { 30\% } \\
\text { (Cruiser 350FS) } \\
\text { (neonicotinoid) }\end{array}$ & Seed coating & $\begin{array}{l}180 \mathrm{ml}(63 \mathrm{~g} / 50,000 \\
\text { seeds) }\end{array}$ & $\begin{array}{l}18 \mu \mathrm{l}(6.25 \mathrm{mg} / 5 \\
\text { seeds) }\end{array}$ & $\begin{array}{l}3.6 \mu \mathrm{l}(1.25 \mathrm{mg} / \\
\text { seed })\end{array}$ & $\begin{array}{l}3.6 \mu \mathrm{l}(1.25 \mathrm{mg} / \\
\text { seed })\end{array}$ & $1(3 ; 15), 2(4 ; 20)$ \\
\hline \multicolumn{7}{|l|}{ Negative controls } \\
\hline Untreated-infested & - & - & - & - & - & $\begin{array}{l}1(3 ; 15), 2(4 ; 20), 3 \\
\quad(3 ; 15)\end{array}$ \\
\hline $\begin{array}{l}\text { Untreated un- } \\
\text { infested }\end{array}$ & - & - & - & - & - & $\begin{array}{l}1(3 ; 15), 2(4 ; 20), 3 \\
(3 ; 15)\end{array}$ \\
\hline
\end{tabular}

About $2 \times 10 \mathrm{~cm}$ treatment strips along soil surface in the pots extrapolated to hectare doses of products for 13,300 row meters. 1.5 I soil in pots with maize plants used. Plants of experiment 1 and 3 infested with 50 ready-to-hatch eggs each, and of experiment 2 with 100 eggs. Block numbers reflect the within experiment replicates. Plants numbers reflect the sample size per treatment per experiment

s Standard doses

a Similar to Avana ${ }^{\mathrm{TM}}$ by Parry Americaa

nimbin and fatty acids). The granules were of 2 to $3 \mathrm{~mm}$ size (Formulation G of GIFAP code) and of slow release.

As a comparison, a common fluid formulation (NeemAzal $^{\mathrm{TM}} \mathrm{T} / \mathrm{S}$, Trifolio-M, Germany) was used in artificial diet-based bioassays. It contained $1 \%$ azadirachtin A originating from $4 \%$ neem seed extract (Azadirachta indica tree), but with unknown concentration of other neem compounds.

Tefluthrin served as a positive control (Tables 1 and 2). The product Force ${ }^{\mathrm{TM}} 1.5 \mathrm{G}$ (Syngenta, Hungary) are fine granules ( 1 to $2 \mathrm{~mm}$ diameter, Formulation FG of GIFAP code) with $1.5 \%$ active ingredient.

Cypermethrin served as a positive control (Tables 1 and 2). The product Belem ${ }^{\text {TM }}$ 0.8MG (Certis, SBM Development SAS, France) are micro granules (0.8 to $1 \mathrm{~mm}$ diameter, Formulation MG of GIFAP code) with $0.8 \%$ active ingredient.

Imidacloprid served as a positive control in the artificial diet-based bioassays in the laboratory (Table 1). The product Confidor $^{\mathrm{TM}}$ 200SL $(17.8 \% \mathrm{w} / \mathrm{w}$ imidacloprid,
Bayer Crop Science, Germany) is a soluble concentrate (SL of GIFAP code) with about $20 \%$ active ingredient.

Thiamethoxam served as a positive control in the potted-plant greenhouse experiments (Table 2). The product Cruiser $^{\mathrm{TM}} 350 \mathrm{FS}$ ( 25 to $30 \% \mathrm{w} / \mathrm{w}$ thiamethoxam, Syngenta, Hungary) is a suspension concentrate for seed treatments (FS of GIFAP code) with about 30\% active ingredient.

\section{Artificial diet-based laboratory bioassays Experimental setup}

To assess lethal doses of azadirachtin on neonates of $D$. v. virgifera, artificial diet-based bioassays with different dosage were conducted in three replicates under controlled semi-sterile conditions (Table 1). Azadirachtin from a common fluid formulation was compared with a novel granular formulation. The insecticides cypermethrin, tefluthrin and imidacloprid served as positive control. Sterilised tap water or no treatment at all served as negative controls. Each bioassay consisted 
of 3 to 6 polystyrene plates of 96 wells each (07-6096 of Biologix Ltd., USA, or Costar 3917 of Corning Inc., USA). Each well was of $330 \mu \mathrm{l}$ volume with $5 \mathrm{~mm}$ in diameter and $10 \mathrm{~mm}$ height, and had a $0.34 \mathrm{~cm}^{2}$ surface. Each treatment was applied to 8 wells of each plate per bioassay. Each treatment-dose combination was tested in at least in two true replicates.

The larval diet for a bioassay had been prepared 1 day before treatment and infestation. The diet was prepared under semi-sterile conditions following methods of Sutter et al. (1971); Pleau et al. (2002), Moar et al. (2017), Clark and Boland (2016, Genective, pers. comm.). A commercial southern corn rootworm diet was used (Frontier \#F9800B, Frontier Scientific Ltd., USA), but maize roots and food colour were added. This diet consists of $\mathrm{D}(+)$ sucrose, vitamin-free casein, cellulose, Wesson's salt mix, methyl paraben fungicide, sorbic acid, cholesterol, raw wheat germ, Vanderzant's vitamin mix, raw linseed oil, streptomycin sulphate antibiotic, and chlortetracycline antibiotic. For $100 \mathrm{ml}$ of diet, $13.8 \mathrm{~g}$ of the \#F9800B diet was grinded and added to $88 \mathrm{ml}$ fluid 60 to $70{ }^{\circ} \mathrm{C}$ agar (1.5 g agar CAS 9002-18-0, Chejeter, Japan in deionized water). After blending and cooling to 55 to $60{ }^{\circ} \mathrm{C}, 0.75 \mathrm{~g}$ grinded lyophilized maize roots were added (GLH5939 Pioneer, USA, or Phileaxx RAGT, Hungary) as well as $0.1 \mathrm{~g}$ green food colour for better larvae observation (Les Artistes, France). Thereafter, 1.7 to $1.8 \mathrm{ml} 10 \% \mathrm{w} / \mathrm{v} \mathrm{KOH}$ were added to reach a $\mathrm{pH}$ between 6.2 and 6.5. This mix was blended again, and then stirred at 50 to $55^{\circ} \mathrm{C}$. Then, $190 \mu \mathrm{l}$ diet was pipetted into each $330 \mu \mathrm{l}$ well filling each to around 2/3rd (repeater pipette P-8, Topscien Co., Ltd, China). Plates with diet were allowed to dry in a laminar flow cabinet during $45 \mathrm{~min}$, and then stored at 3 to $5{ }^{\circ} \mathrm{C}$ overnight. The following day, treatments were applied. This is, $20 \mu \mathrm{l}$ of a treatment were applied to the $0.34 \mathrm{~cm}^{2}$ diet surface in each well (10 to $100 \mu$ pipette, Biohit Proline, Finland). Order of treatments were shifted every other plate to avoid edge effects. Plates were dried for 1 to $1.5 \mathrm{~h}$, and then cooled for $1 \mathrm{~h}$ in a 3 to $5{ }^{\circ} \mathrm{C}$ fridge.

Two weeks prior the bioassays, soil dishes with freshly laid eggs had been removed from $D$. v. virgifera adult rearing cages to allow sufficient incubation time until egg hatch. Eggs were washed with cool tap water with $<0.01 \%$ $\mathrm{NaOCl}$ through a $300 \mu \mathrm{m}$ mesh sieve. Around 5000 eggs were transferred to sterilised, slightly moist river sand $(<200 \mu \mathrm{m}$ grains) in Petri dishes. They were incubated at $24 \pm 2{ }^{\circ} \mathrm{C}$ in darkness for 8 to 12 days until hatching started. One day before a bioassay, the ready-to-hatch eggs were again washed and sieved. Eggs were then again mixed into sterile moist sand and placed onto slightly moist tissue paper into a dish to allow clean hatching conditions of new neonates and their use for bioassays.
One neonate larva was placed per well using a fine artist brush. A fast-moving, healthy-looking larva was chosen, and lifted from the end of abdomen with the brush, moved towards a well surface, and allowed to crawl off the brush onto the diet. Larvae were not placed in treatment column order but rectangular to avoid systemic errors. After every 12th larva, the brush was cleaned in $70 \%$ ethanol followed by sterile tap water. The filled plate was closed with an optically clear adhesive qPCR seal sheet (\#AB-1170, Thermo Scientific, USA or \#BS3017000, Bioleader, USA) allowing data assessments without opening the plate. Four to five holes were made with flamed 00 -insect pins into the seal per well to allow aeration.

The plates were incubated at $24 \pm 2{ }^{\circ} \mathrm{C}$ and 50 to $70 \%$ r.h. in dark in a ventilated incubator (Friocell 22, MMM Medcenter, Munich, Germany) for 5 days.

\section{Data assessments and analyses}

After 3 and 5 days of incubation, larval mortality, stunting, feeding and contamination were visually assessed through the clear seals using a stereomicroscope $(10 \times$ magnification, SMZ-B4, Optec, Chongqing, China). Data from a plate were only used when the natural mortality threshold in the untreated control had not been reached, i.e. no more than 3 dead per 8 larvae per column of wells (37.5\% threshold). This is in contrast to common practices in bioassays with other insects where the quality acceptance is usually $<10 \%$ natural background mortality (Dulmage et al. 1990). However, this is rarely achievable with rootworm larvae as the artificial diets known to date remain suboptimal (Hibbard, University of Missouri, 2019, pers. comm.; Huynh et al. 2018).

Stunting was qualitatively assessed as an indicator for sublethal effects in comparison to the size and form of larvae in the untreated control. Feeding was assessed through observing food remains, frass, and diet in the larval gut to assure that diet and a treatment had been ingested. The coefficient of variation (CV) was determined in each bioassay as a measure of data precisions. A CV should ideally be $<0.2$, and at a CV of $>2$ further bioassays would be needed (Dulmage et al. 1990). In our experiments, the CVs of 1.2 for bioassay $1,0.4$ for bioassay 2, 0.7 for bioassay 3 , and 0.8 for all bioassays, indicated good quality of data (Additional file 1: Table).

Larval data were compared between treatments within each experiment using Chi-Square statistics (because of nominal data type) with an fdr-correction of p-values (Benjamini and Hochberg 1995). To allow across-experiments comparisons, data were standardised to the untreated control data. Distributions of data were investigated using histograms, normal and detrended normal probability Q-Q plots and one-sample 
Kolmogorov-Smirnov test (Kinnear and Gray 2000). Equality of variances was assessed using Levene's test. When data appeared normal distributed, influences of treatments were analysed through unifactorial Generalized Linear Model (GLM) and multiple comparisons were applied using Tukey HSD post hoc comparison of data of equal variances and Games Howell post hoc comparison for unequal variances. Logistic regression analyses were applied to assess the dose response of each treatment including lethal dose leading to $50 \%$ or $90 \%$ mortality $\left(\mathrm{LD}_{50 / 90}\right)$ ( $\mathrm{R}$ package MASS) and McFadden pseudo R-square values (package DescTools, R Development Core Team 2020).

\section{Potted-plant greenhouse experiments Experimental setup}

To assess the efficacy of azadirachtin granules against D. v. virgifera larvae under semi-natural conditions, three systematic controlled trials were conducted using infested potted-maize plants in a greenhouse. As positive control served tefluthrin fine granules, cypermethrin microgranules and thiamethoxam-seed coating (Table 2). As negative controls served untreated infested plants as well as untreated uninfested plants. Each treatment was applied into the soil of three to four systematically arranged blocks (= replicates) of five pots. This totalled 15 to 20 data points (=sample size) per treatment per experiment.

In detail, each pot (plastic garden pot, $15 \mathrm{~cm}$ inner diameter $\times 10 \mathrm{~cm}$ height, $2 \mathrm{l}$ ) was first filled with $11 \mathrm{steri}$ lised soil. Two maize seeds were added (hybrid Szegedi 386, GK Hungary in experiment 1 and 3, or Futurixx, RAGT, France in experiment 2). Thereafter, $200 \mathrm{ml}$ water were applied to each pot. Treatments were applied either as granules along a $2 \mathrm{~cm}$ wide strip across the $10 \mathrm{~cm}$ diameter of the pots, or as seed coating. Finally, $1 / 2 \mathrm{l}$ soil was added burying the treatment and seed $3 \mathrm{~cm}$ into the soil leading to a soil surface of $14 \mathrm{~cm}$ diameter. The used soil contained $77 \%$ sand, $8 \%$ loam, $15 \%$ clay, $2.8 \%$ humus, $1.7 \% \mathrm{CaCO}_{3}, 0.1 \%$ salts, and had a Ph of 7.7 (analysed by Szolnoki Talajvedelmi Laboratorium, Hungary). It had a soil bulk density 0.9 to $1.1 \mathrm{~g} \mathrm{~cm}^{-3}$ and a 7 to $11 \%$ soil moisture (w\%=grav.\%). An average temperature of $20 \pm 5{ }^{\circ} \mathrm{C}$ and a relative humidity of $97 \pm 3 \%$ were recorded $5 \mathrm{~cm}$ deep in the soil in the pots as well as $24 \pm 4{ }^{\circ} \mathrm{C}$ and $44 \pm 13 \%$ in the air $1 \mathrm{~m}$ above the pots using climate data loggers (PeakTech 5185 data logger, Germany). Plants germinated between 4 and 12 days after sowing.

Maize pots were infested with 50 viable ready-tohatch eggs per plant in experiment 1 and 3 or with 100 eggs in experiment 2. At this point in time, the majority of plants was at 3 leaf stage (height 15 to $20 \mathrm{~cm}$ ). The eggs were applied in 0.15 to $0.2 \%$ aqueous agar with a standard pipette (1 to $5 \mathrm{ml}$, Eppendorf AG, Germany) in half-portions into two $50 \mathrm{~mm}$ deep holes 20 to $30 \mathrm{~mm}$ distant from both sides of the plant. A portion of eggs was incubated on moist filter paper at $20{ }^{\circ} \mathrm{C}$ in the laboratory to estimate emergence patterns ( 5 dishes with 10 to 20 eggs each/experiment). They revealed an emergence start $9 \pm 5$ days after placement. Hatching duration was $10 \pm 4$ days. Hatching rate was $47 \pm 30,47 \pm 23 \%$ and $56 \pm 19$, leading to 24 hatched larvae per pot in experiment 1, 47 larvae in experiment 2 , and 28 larvae in experiment 3 , respectively. This indicates a medium, but consistent egg quality across experiments, and is comparable to similar studies of Xie et al. (1991).

\section{Data assessments and analyses}

Selectivity of the test agents was assessed by recording germination rate, plant phenology and phytotoxicity. Leaf number, plant height and the $\mathrm{BBCH}$ growth stage were assessed weekly as well as phytotoxicity according to Anonymous (2009).

At the expected second and early third instar stage, numbers of surviving larvae, root damage and above-ground biomass were assessed. This was $52 \pm 18$ days after planting and treatment, thus $40 \pm 7$ days after infestation. Each maize plant was pulled out of the soil, and gently shaken to remove loosely adhering soil particles from roots. Each maize plant was cut $1 \mathrm{~cm}$ above roots, and fresh weight, leaf number and plant height were measured. Then, the soil and root of each pot was placed onto a plastic screen for drying out and letting surviving larvae exit and drop onto the wet tissue paper in a tray below following a Berlese approach (Dent and Walton 1998). Larvae and their instars were counted $1,3,5$ and 7 days later.

The untreated control was aimed to have a minimum level of infestation with 2nd or 3rd instar larvae of $20 \%$ to validate the results on agent efficacies. In all experiments, more than $90 \%$ of pots of the infested untreated second control yielded larvae. The infested control lead to $6 \pm 5 \mathrm{~s}$ or third instar larvae/100 applied eggs.

One day after Berlese-placement, the dried roots were removed, gently shaken to remove remaining soil, soaked in water for $5 \mathrm{~min}$, and then washed in $1 \% \mathrm{NaOCl}$ and then water for $1 \mathrm{~min}$ to allow the assessment of root damage. Damage was rated using two scales recommended by EPPO (Anonymous 1999); this is, (1) the non-linear 1.0 to 6.0 traditional IOWA scale (Hills and Peters 1971) which slightly overestimates minor damage; and (2) the linear 0.00 to 3.00 node injury scale (Oleson et al. 2005) which measures only destroyed roots and therefore misses minor damage. To avoid subjective bias on these ratings, root damage was estimated independently by the experimenters, neither of whom knew whether the roots were from a treated or untreated pot. 
Distributions of data were investigated using histograms as well as normal and detrended normal probability Q-Q plots (Kinnear and Gray 2000). Equality of variances was assessed using Levene's test. Influences of treatments on assessed factors were analysed through GLM analyses or through independent samples KruskalWallis $\mathrm{H}$ test. Tukey HSD post hoc multiple comparison tests were applied following GLM in case of equal variances, and Games Howell test in case of unequal variances. Logistic regression analyses were applied to assess the dose response of each treatment including the effective dose leading to $50 \%$ suppression of the larval populations or root damage prevention $\left(\mathrm{ED}_{50}\right)$ The mean corrected efficacy of each treatment was calculated relative to the untreated control, this is corrected efficacy $\%=100 \times$ (larvae or damage in control plots - larvae or damage in treated plots)/maximum (larvae or damage in control or treated plots) (Toth et al. 2020). As the 1.0 to 6.0 IOWA root damage scale is a non-linear ordinal scale, and a value of 1 equals no damage, the damage data were converted to a 0.0 to 5.0 scale to estimate percent damage prevention across experiments. Results from azadirachtin treatments were validated in relation to the results from the corresponding positive controls of standard insecticides.

\section{Results}

\section{Control of neonates in artificial-diet based laboratory bioassays}

Azadirachtin appeared toxic to neonates of $D . v$. virigifera larvae (Figs. 1, 2, Additional file 1: Table). A clear dose-mortality response was observed. The corresponding fit of a logistic regression 3 days after treatment was: larval mortality $(3 d)=1 /(1+\exp (2.22-0.71 * \ln (d$ ose)) (Chi-square test for $\ln$ of dose: $\mathrm{p}<0.0001, \mathrm{df}=67$; McFadden pseudo $\mathrm{R}^{2}=0.70$, Fig. 1). Accordingly, the 3 -day $\mathrm{LD}_{50}$ of azadirachtin was estimated $22.3 \mu \mathrm{g}$ active ingredient (a.i.)/ml ( $\mathrm{CI}_{95 \%} 8.8-56 \mu \mathrm{g}$ a.i./ml). This corresponds to $1.34 \mu \mathrm{g}$ a.i. $/ \mathrm{cm}^{2}$ treated surface, and to $0.45 \mu \mathrm{g}$ a.i./20 $\mu \mathrm{l} /$ larva. The 3 -day $\mathrm{LD}_{90}$ was $480 \mu \mathrm{g}$ a.i./ml (CI $95 \%$ 92-2742 $\mu \mathrm{g})$.

The dose-response did not change much from day 3 until day 5. The 5-day $\mathrm{LD}_{50}$ was $19.3 \mu \mathrm{g}$ a.i./ml (CI $95 \%$ : 7.3-51.2 $\mu \mathrm{g})$ according to the logistic regression fit: larval mortality $(5 d)=1 /(1+\exp (1.99-0.67 * \ln ($ dose $))($ Chisquare test for $\ln$ of dose: $\mathrm{p}<0.0001$, McFadden pseudo $\left.\mathrm{R}^{2}=0.68\right)$. This corresponds to $1.16 \mu \mathrm{g}$ a.i. $/ \mathrm{cm}^{2}$ treated surface, and to $0.39 \mu \mathrm{g}$ a.i./20 $\mu \mathrm{l} /$ larva. The 5 -day $\mathrm{LD}_{90}$ was $502 \mu \mathrm{g}$ a.i./ml (CI $95 \% 94-2746 \mu \mathrm{g})$.

No sublethal effects of azadirachtin such as stunting of larvae were observed (ANOVA for logarithmic model: $\mathrm{F}_{1 ; 41}=1, \mathrm{p}=0.31$, adjusted $\left.\mathrm{R}^{2}=0.001\right)$.

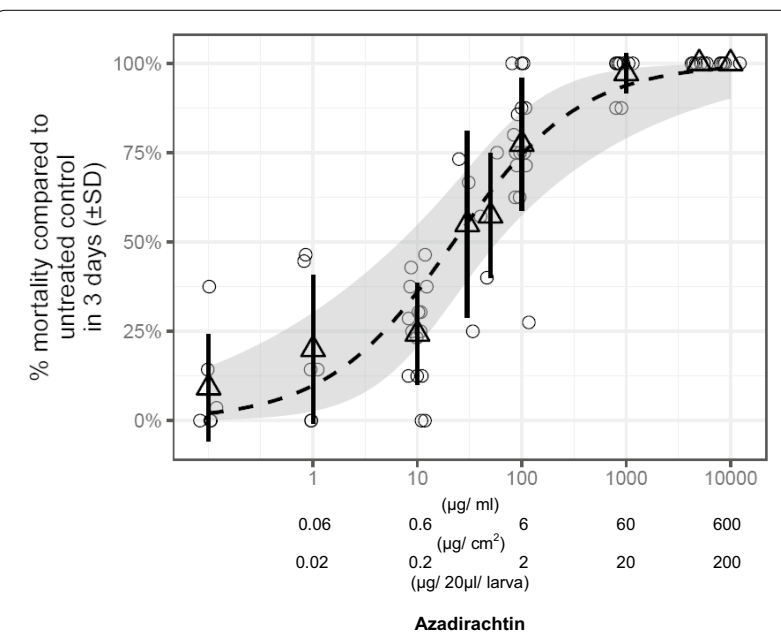

Fig. 1 Dose-efficacy response of azadirachtin in killing neonates of Diabrotica v. virgifera in artificial diet-based bioassays of 96-well plates under semi-sterile laboratory conditions. Corrected mortality shown, i.e. standardised for natural background mortality in the untreated control. Fluid neem product used (NeemAzal-T/S 10EC). 3 experiments as true replicates with $\Delta$ representing the mean values. 8 wells per treatment per each of 6 plates per each experiment. Trendline added of fitted logistic regression model: larval mortality $(3 d)=1 /(1+\exp (2.22-0.71 * \ln ($ dose $))$ with confidence interval of the fitted line in grey

\section{Control of larvae and prevention of root damage in potted -plant greenhouse experiments}

Azadirachtin treatments at increasing dose reduced the larval survival on the maize roots (relative to control, GLM, $\mathrm{F}_{5 ; 30}=17.6, \mathrm{p}<0.0001$, adjusted $\mathrm{R}^{2}=0.73$ ).

Multiple comparison tests revealed efficient control of D. virgifera larvae on maize roots by standard doses of tefluthrin and thiamethoxam, but not by standard doses of cypermethrin and azadirachtin (Figs. 3, 4). When increasing doses of azadirachtin, control of larvae became evident. Between 25 and $67 \%$ of larvae were killed by a $5 \times$ standard-dose (200 g a.i./ha), and $100 \%$ control efficacy was reached at a $10 \times$ standard-dose (380 g a.i./ha). Doubling the standard dose of cypermethrin did not improve its efficacy in reducing larvae numbers.

The corresponding logistic regression fit of efficacy to different doses of azadirachtin was: efficacy in reducing larvae $(\%)=1 /(1+\exp (2.203-1.14 * \ln$ (dose) (Chi-square test for $\ln$ of dose: $\mathrm{p}=0.0027, \mathrm{df}=19$; McFadden pseudo $\mathrm{R}^{2}=0.43$, Fig. 3). Accordingly, the $\mathrm{ED}_{50}$ of azadirachtin was $6.9 \mathrm{mg}$ active ingredient/meter of maize furrow (CI 95\% $2.6-18.5 \mathrm{mg}$ ). This corresponds to approximately $92 \mathrm{~g}$ azadirachtin/hectare. The $\mathrm{ED}_{90}$ was $47.7 \mathrm{mg}$ active ingre$\mathrm{dient} /$ meter of maize (CI $95 \% 5.2-430 \mathrm{mg}$ ).

Reduction of larvae through treatments was only partly reflected in the level of prevention in root damage (Figs. 5, 6). Azadirachtin treatments at increasing dose 


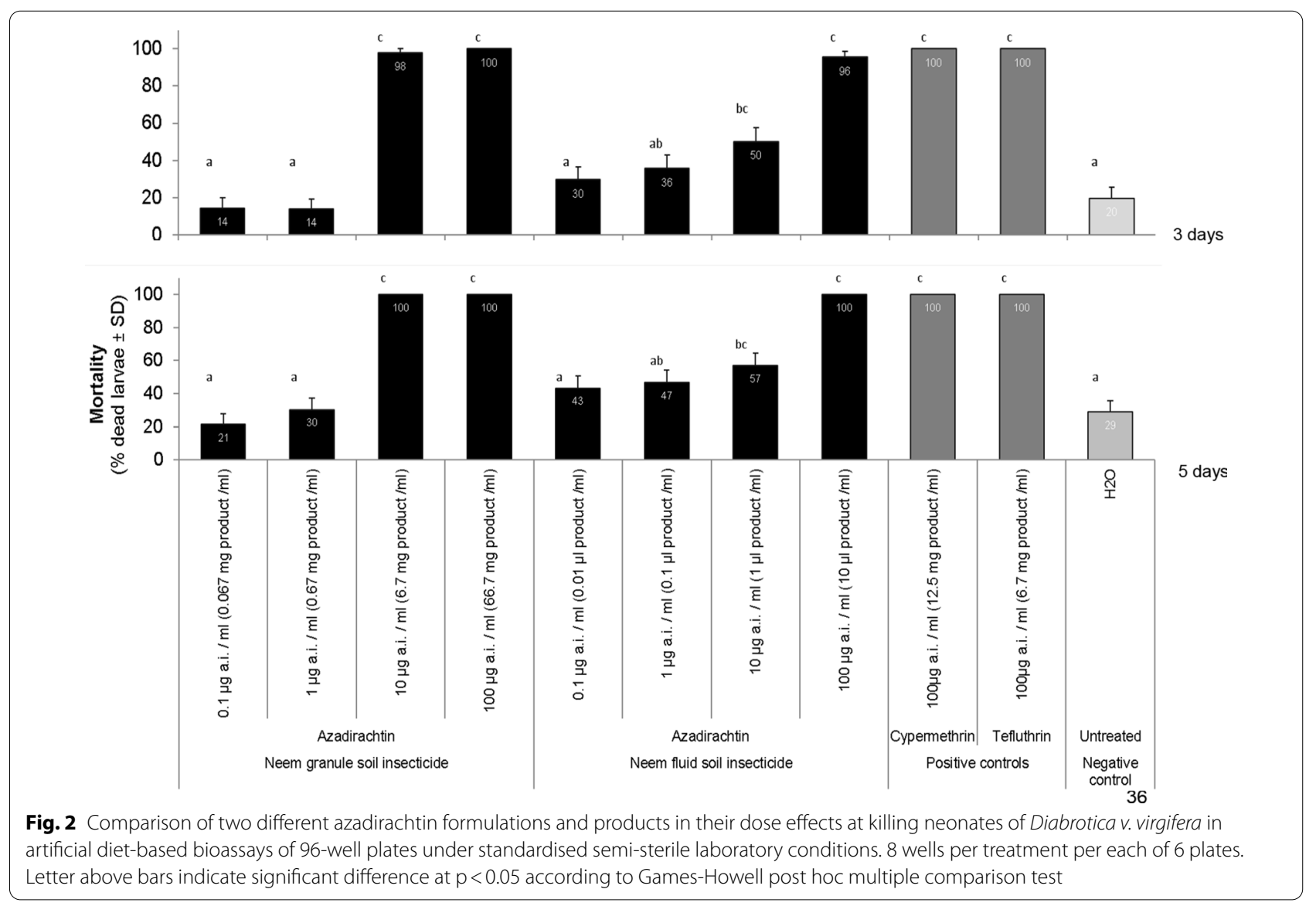

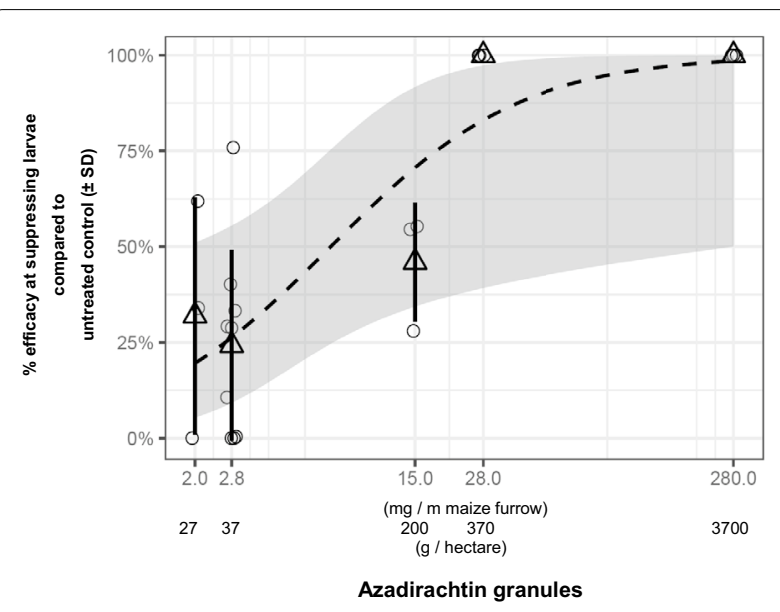

Fig. 3 Dose-efficacy response of azadirachtin granules in reducing larvae of Diabrotica v. virgifera in three potted-maize plant trials under greenhouse conditions in Hungary in 2020. Granular neem product for soil applications used (Neem Azaal 0.15G). Corrected efficacy shown, i.e. standardised to the untreated control data. Plant roots artificially infested with 50 to 100 eggs. Trendline added of fitted logistic regression model, with confidence interval of fitted line in grey improved the level of prevention in root damage (relative to control, GLM, $\mathrm{F}_{5 ; 30}=29.5$ for general root damage, 22.5 for heavy root damage, adjusted $\mathrm{R}^{2}=0.83$ and 0.78 ; $\mathrm{p}<0.0001)$.

Multiple comparison tests revealed that standard dose of tefluthrin and thiamethoxam consistently prevented the overall as well as heavy root damage (Fig. 4). The standard dose of cypermethrin only inconsistently prevented some of the root damage and the standard doses of azadirachtin was usually not sufficient. When increasing the doses of azadirachtin, prevention of root damage became evident. About $40 \%$ of the overall root damage and $67 \%$ of the heavy root damage were prevented by a $5 \times$ standard-dose (200 g a.i./ha). Root damage was nearly entirely prevented by a $10 \times$-standard-dose ( $380 \mathrm{~g}$ a.i./ha).

The corresponding logistic regression fit of root damage prevention to different doses of azadirachtin was: efficacy in preventing general root damage $(\%)=1 /(1+e$ $x p(2.39-0.85 * \ln ($ dose $))($ Chi-square test for $\ln$ of dose: $\mathrm{p}=0.0075, \mathrm{df}=19$; McFadden pseudo $\mathrm{R}^{2}=0.55$, Fig. 3). Accordingly, the $\mathrm{ED}_{50}$ of azadirachtin was $16.5 \mathrm{mg}$ active ingredient/meter of maize furrow (CI ${ }_{95 \%} 4.2-65.9 \mathrm{mg}$ ). This corresponds to approximately 220 g azadirachtin/ 


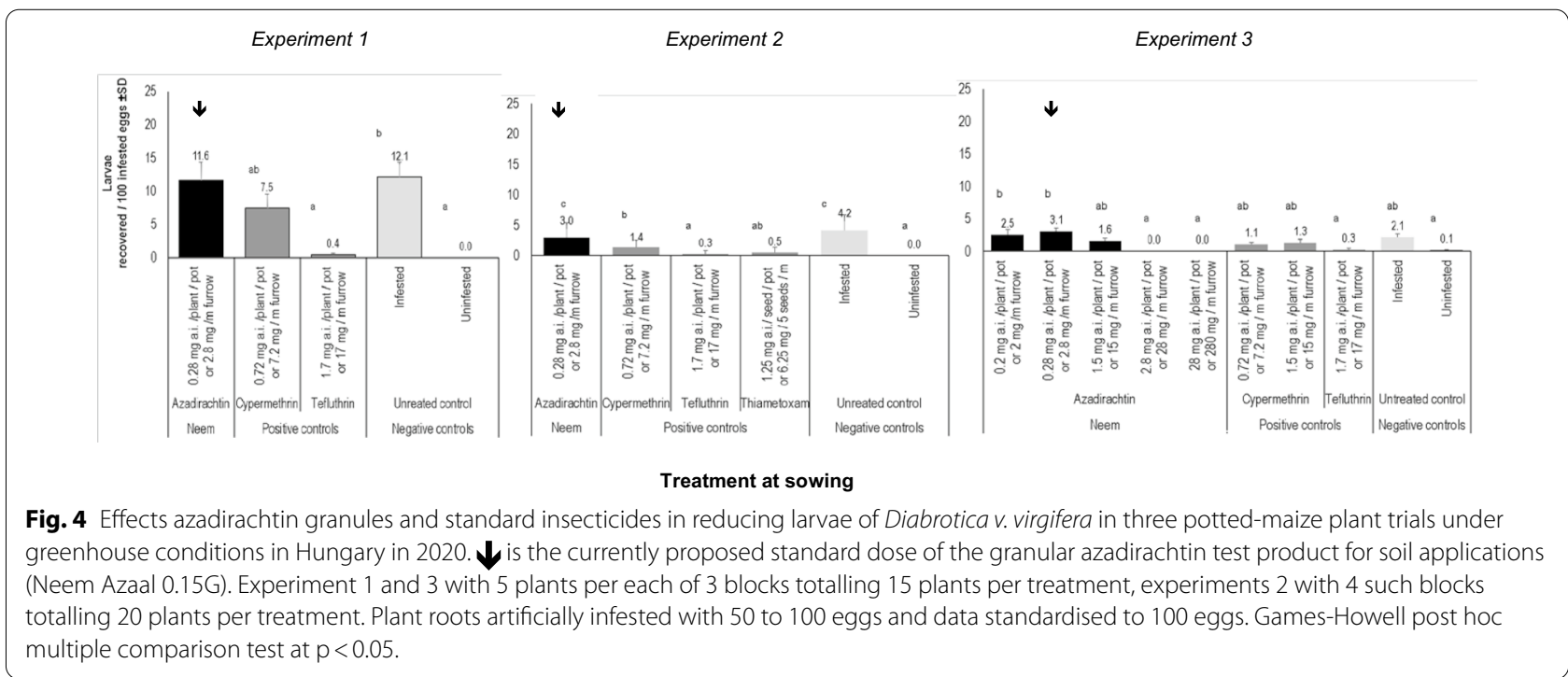

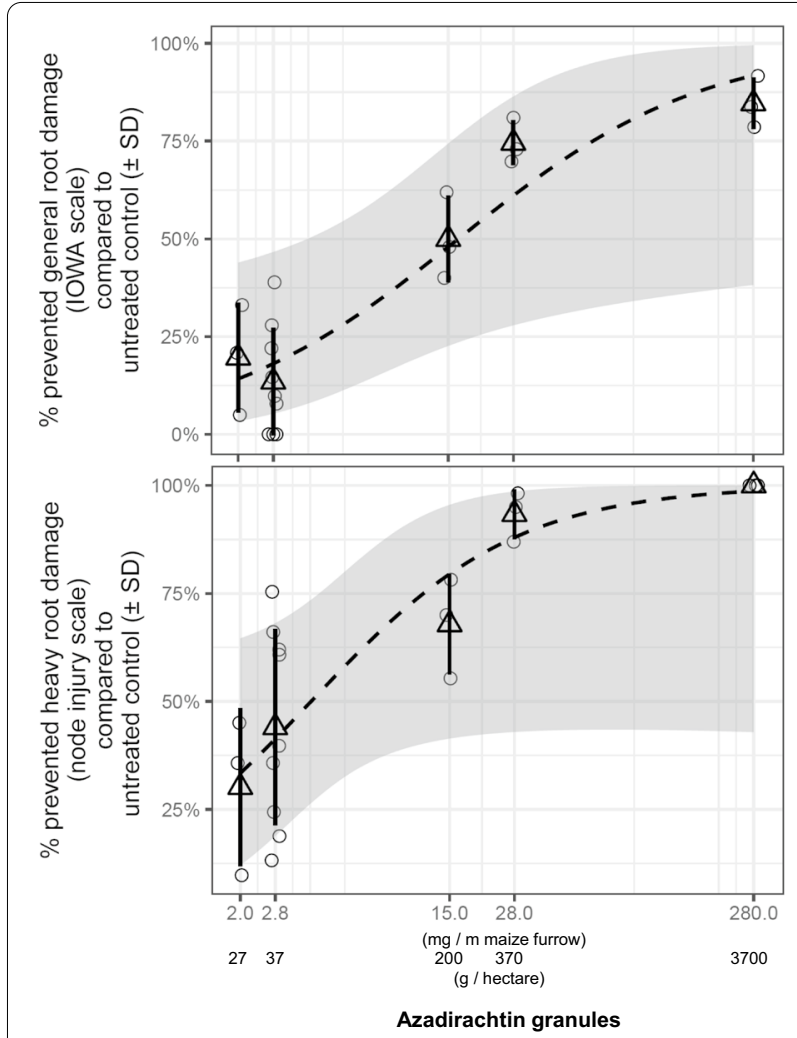

Fig. 5 Dose-efficacy response of azadirachtin granules in preventing root damage caused by Diabrotica $v$. virgifera in three potted -maize plant trials under greenhouse conditions in Hungary in 2020. Granular neem product for soil applications used (Neem Azaal 0.15G). General root damage assessed through 1.0 to 6.0 traditional IOWA scale (Hills and Peters 1971) and heavy root damage through 0.00 to 3.00 node- injury scale (Oleson et al. 2005). Corrected efficacy shown, i.e. standardised to the untreated control data. Plant roots artificially infested with 50 to 100 eggs. Trendline added of fitted logistic regression model with confidence interval of fitted line in grey hectare. The $\mathrm{ED}_{90}$ was $218 \mathrm{mg}$ a.i. /meter of maize furrow (CI ${ }_{95 \%}$ 9.-5277 mg).

The logistic regression fit of preventing heavy damage to different doses was: efficacy in preventing heavy root damage $(\%)=1 /\left(1+\exp \left(1.397-1.016^{*} \ln (\right.\right.$ dose $\left.)\right)($ Chisquare test for $\ln$ of dose: $\mathrm{p}=0.011, \mathrm{df}=19$; McFadden pseudo $\mathrm{R}^{2}=0.39$, Fig. 3 ). The corresponding $\mathrm{ED}_{50}$ of azadirachtin was $3.96 \mathrm{mg}$ active ingredient/meter of maize furrow according to the logistic model fit (CI $95 \%$ $1.4-10.8 \mathrm{mg})$. This corresponds to approximately $52 \mathrm{~g}$ a.i./ha. The $\mathrm{ED}_{90}$ was $34.4 \mathrm{mg}$ active ingredient/meter maize furrow (CI 95\% 3-392 mg).

Preventing root damage through certain treatments was only little reflected in yield-related parameters. When differences were found between treatments and the untreated control, then their absolute differences were small.

Whilst the standard dose of azadirachtin and up to $2.8 \mathrm{mg}$ a.i./plant/pot $(28 \mathrm{mg} / \mathrm{m}$ furrow $)$ did not improve biomass of 6 to 10 leaf stage maize, a high dose of $28 \mathrm{mg}$ azadirachtin $(280 \mathrm{mg} / \mathrm{m})$ improved biomass $(8.3 \pm 2.7 \mathrm{~g}$ versus $3.9 \pm 2$ of infested control plants, GLM, $F_{5 ; 30}=16$, adjusted $\left.R^{2}=0.72 ; \mathrm{p}<0.0001\right)$. The standard dose of tefluthrin also improved biomass in one of three experiments, but no such improvements were detected by cypermethrin or thiamethoxam.

Whilst the standard dose of azadirachtin and up to $1.5 \mathrm{mg}$ a.i./plant/pot (15 mg/m furrow) did not improve height of maize, a high dose of $2.8 \mathrm{mg}$ azadirachtin $(28 \mathrm{mg} / \mathrm{m})$ or even $28 \mathrm{mg}(280 \mathrm{mg})$ increased plant height $(49 \pm 11 \mathrm{~cm}$ or $50 \pm 11 \mathrm{~cm}$ versus $36 \pm 15 \mathrm{~cm}$ of infested control plants, GLM, $\mathrm{F}_{5 ; 30}=3.9$, adjusted $\mathrm{R}^{2}=0.33 ; \mathrm{p}=0.009$ ). The standard doses of tefluthrin, 


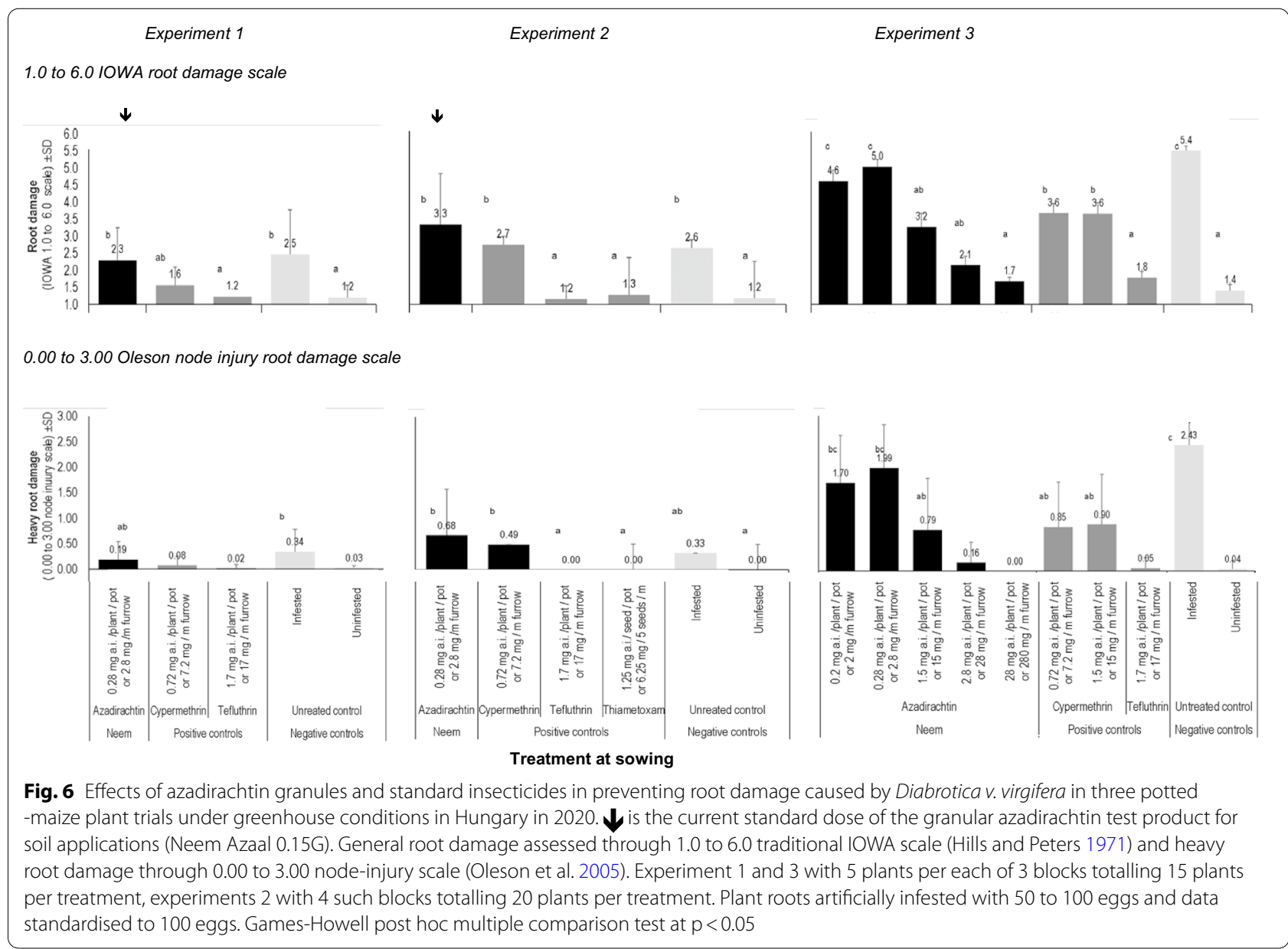

cypermethrin or thiamethoxam did not affect plant height in none of the experiments.

None of the treatments and applied doses did increase average leaf numbers of 6 to 10 leaf stage maize, except of a small positive effect of thiamethoxam in experiment $2(9.3 \pm 0.9$ versus $8.5 \pm 0.7$ leaves of infested control plants).

Treatments did not affect germination rates (GLM, $\left.\mathrm{F}_{12 ; 76}=1.25 ; \mathrm{p}=0.27\right)$ and did not lead to any delay in germination $(F=0.8 ; p=0.58)$ regardless of azadirachtin or synthetic pesticides and regardless of the different doses being applied. Those treatments also did not cause any phytotoxic effects such as yellowing, chlorosis, necrosis or deformation of leaves or stunting of plants.

\section{Discussion}

Our sets of laboratory-bioassays as well as potted-plant experiments confirmed Xie et al. (1991) that the neem plant-derived azadirachtin is toxic to larvae of Diabrotica v. virgifera, one of the key pests among rootworms. This is not surprising as azadirachtins are of broad-spectrum activity (Dougoud et al. 2019). Positively, an application of this botanical insecticide as a granule into the sowing furrow can lead to a suppression of the later hatching larvae and to a significant prevention of root damage. Granule applications at sowing are preferred by many maize growers over fluid applications or applications later in the maize growing season (Toepfer et al. 2010). This should be of high interest to industry because of recent bans on the use of a number of soil insecticides and insecticidal seed-coatings due of their either high human toxicity and/or serious non-target effects or other environmental concerns (World Health Organization 2009; EuropeanCommission 2011; Georgiadis et al. 2011).

Consequently, growers in numerous countries are left with few or no management options for soil insect pests in field crops. However, soil insects, such as corn rootworms (Diabrotica spp.), cutworms (Agrotis spp.), wireworms (Agriotes spp.) or grubs (Melolonthidae) account for a large proportion of below-ground damage to maize, and the latter two pest groups also to a number of other crops (Toepfer et al. 2014). In Hungary for example, $46 \%$ of all the 5000 tons of insecticides sold in 2019 were the granular soil insecticide tefluthrin (Demeter and Lazar 
2020). This indicates the high importance of such insecticides for the control of soil insect. However, tefluthrin will probably be retreated from the pesticide markets due to its high toxicity being classified as a WHO-class Ib acutely hazardous ingredient (World Health Organization 2009). Similarly, neonicotinoids have already been phased-out in many countries due to their pollinator toxicity, accumulation in the soil and other environmental effects (Georgiadis et al. 2011). Agri-policies try to address the public concerns with regard to pesticides and try to promote alternative and safer pest management solutions. Examples of such attempts aare the directive on "Sustainable Pesticide Use" of the European Union (European Commission 2009) or the "Green Pest Control Policy" of China (Fan 2006; MoA 2011). However, such policies do not necessarily lead to new pest control options, as the discovery and development of novel plant protection agents with new modes of action and low enviormental impact is difficult and costly.

We have therefore investigated whether the safe and easily biodegradable botanical insecticide azadirachtin (Boeke et al. 2004), which is widely used against aboveground insects (Saxena 1989), might become an option for the control of soil insect pests. First, we confirmed through laboratory bioassays that the azadirachtins in the here-tested granular formulation were similarly effective as the ones in commonly used fluid formulations. This was necessary because neem products can be variable in their contents of active ingredient(s) as well as in their efficacy for pest control (Stark and Walter 1995; Dougoud et al. 2019). Therefore, the provider of the neem granules had run gas chromatographic analyses prior our experimentation confirming $0.165 \%$ azadirachtin as labelled (mainly A with some B) as well as $0.35 \%$ other neem compounds (Aza-F, Aza-H, Aza-I, salanin, nimbin and fatty acids). This is important, because in many neem products, the ingredients are not well assessed and/or declared on the product label (Dougoud et al. 2019). In our bioassays, the dose-response curves of azadirachtin from the granular formulation did not differ from those in common fluid formulations (Fig. 2), indicating a good quality of the test products and correctness of label information.

Our artificial diet-based bioassays on neonates of D. v. virgifera larvae revealed a 3 -day $\mathrm{LD}_{50}$ of $22.3 \mu \mathrm{g}$ azadirachtin $/ \mathrm{ml}$ which corresponds to $0.45 \mu \mathrm{g} /$ neonate. Azadirachtin appeared of relatively fast mode of action on $D$. v. virgifera as the dose-response did not change much from day 3 to day 5 . The 5 -day $\mathrm{LD}_{50}$ was $19.3 \mu \mathrm{g} /$ $\mathrm{ml}$ which corresponds to $0.39 \mu \mathrm{g} /$ neonate up to early second instar larva. Also, Xie et al. (1991); Stark and Rangus (1994) and a number of other authors suggested that azadirachtin has contact activity on insects in addition to its widely reported systemic and chronic modes of action. There are a number of $\mathrm{LD}_{50}$ reported for immature stages of several insect groups, such as $77 \mu \mathrm{g} / \mathrm{ml}$ for first instar Ectomyelois spp. (Lepidoptera) over 5 days and $438 \mu \mathrm{g} /$ $\mathrm{ml}$ over 1 day (Mehaoua et al. 2013), 7.6 to $7.7 \mu \mathrm{g} / \mathrm{ml}$ for fourth instars of two Culex spp. (Diptera: Culicidae) with not-reported exposure time (Merabti et al. 2017), and $2.8 \mu \mathrm{g} / \mathrm{ml}$ for young Aphis spp. (Hemiptera: Aphididae) over 7 days (Stark and Rangus 1994). Ladd et al. (1984) reported a low $\mathrm{LD}_{50}$ of only $0.1 \mu \mathrm{g}$ of topically applied azadirachtin per third instar Popillia japonica (Coleoptera: Scarabaeidae), but over an exposure of 20 days. This suggests that our reported $\mathrm{LD}_{50}$ by $0.45 \mu \mathrm{g}$ within 3 days or $0.39 \mu \mathrm{g}$ within 5 days for the much smaller neonates of D. $v$ virgifera would be much lower when assessing mortality over longer periods. In general, it appears difficult to compare $\mathrm{LD}_{50}$ across studies and insect species due to different experimental setups particularly the involved insect food, exposure periods, different insect weights, and sometimes unclear compositions of azadirachtins and related compounds in the test agents. Despite the often reported $\mathrm{LD}_{50}$ as $\mu \mathrm{g} / \mathrm{ml}$, some of those studies do not report the amount of azadirachtin applied per larva or per insect weight. For example, Xie et al. (1991) reported a 3-day $\mathrm{LD}_{50}$ of only 3.9 (2.5 to 5.9$) \mu \mathrm{g}$ azadirachtin/ml when applying $1.7 \mathrm{ml}$ of the $3.9 \mu \mathrm{g} / \mathrm{ml}$ solution onto filter paper in a Petri dish with 10 neonates of D. v. virgifera and a maize seedling, thus effectively $6.6 \mu \mathrm{g}$. The reported effective dose seems low compared to our data, and reasons are difficult to explain. On one hand, the experimental arrangements of Xie et al. (1991) with filter paper assays in Petri dishes differs to our approach of exposing one larva to azadirachtin on artificial diet, on the other hand their sample size was low (5 Petri dishes only). Qadri and Narsaiah (1978) reported a 1-day $\mathrm{LD}_{50}$ of $1.5 \mathrm{mg}$ azadirachtin/gram body mass of older nymphs of Periplaneta spp. (Blattodea), but there is no such information for other Diabroticina. Our tested $D$. v. virgifera larvae weighted about $0.42 \pm 0.23 \mathrm{mg}$ (across neonates and young second instars). This would roughly correspond to an $\mathrm{LD}_{50}$ of 0.9 to $1.1 \mathrm{mg}$ azadirachtin/gram D. v. virgifera larva, being comparable with the $\mathrm{LD}_{50}$ on Periplaneta. Astonishingly, we did not detect any sublethal effects of azadirachtin to $D$. v. virgifera larvae such as stunting or moulting inhibition. Some authors reported growth inhibitor and deformation effects to insects, such as to Culex larvae (Al-Sharook et al. 1991) or Aphis nymphs (Stark and Rangus 1994). Landis and Gould (1989) reported anti-feeding effects to larvae of Diabrotica undecimpunctata howardi. Although, in our bioassays some larvae of $D$. v. virgifera moulted to 2nd instar suggesting no inhibitor effects, our assay duration of 5 days might not have been long enough to detect all 
possible sublethal effects. Ladd et al. (1984), for example, detected insect growth regulator effects on Popillia grubs only within about 20 days after treatment. As for rootworms, however, longer assays are rarely achievable as the known artificial insect diets are suboptimal and contamination rapidly occurs due the non-sterile nature of the available diets (Hibbard, University of Missouri, 2019, pers. comm.; Huynh et al. 2019). Nevertheless, the here-reported $\mathrm{LD}_{50}$ levels of azadirachtin of $D$. v. virgifera seem in line with lethal effects to other insect groups, and therefore warranted further investigation.

In a second step, we simulated the efficacy and feasibility of an azadirachtin-based granule application into the soil for corn rootworm control using potted-plant experiments in comparison to standard pesticides. Results showed that standard doses of thiamethoxam-seed coating and tefluthrin-granular soil insecticides applied at maize sowing can well suppress larval populations of $D . v$. virgifera and prevent most root damage (Pilz et al. 2009; Rozen and Ester 2010; Modic et al. 2018; Souza et al. 2020). In contrast, a cypermethrin granular soil insecticide applied at its standard dose at sowing appeared much less effective, and even doubling its dose did not improve efficacy. This confirms variable experiences with cypermethrin-based soil insecticides for rootworm control in field studies (Toth et al. 2020). Unfortunately, also the currently proposed standard dose of $38 \mathrm{~g}$ azadirachtin/hectare for granular in-furrow application at sowing appeared not enough to control $D$. v. virgifera or to prevent root damage. However, when increasing doses of azadirachtin, control of larvae and prevention of root damage became evident. At a $5 \times$ standard-dose of azadirachtin ( $200 \mathrm{~g} / \mathrm{ha}), 25$ to $67 \%$ percent of larvae were killed, about $40 \%$ of overall root damage prevented as well as about $67 \%$ of heavy root damage. This, as well as the modelled $\mathrm{ED}_{50}$ are comparable to or better than the efficacy of most cypermethrin applications. At a $10 \times$ standard-dose azadirachtin ( $380 \mathrm{~g} / \mathrm{ha})$, total pest control was achieved as well as the prevention of most root damage. Whether this would be economically feasible is not yet clear. However, such a control efficacy is even better than the efficacies of most applications of tefluthrin granules and comparable to the efficacy of thiamethoxam seed-coatings. This confirms Xie et al. (1991) who applied high doses of azadirachtin as a drench into the sowing furrow in potted-plant trials. This also indicates that both fluid and granular applications into the furrow at maize sowing would lead to control efficacies. As into-furrow applications of agents in maize seem to have little impact on non-targets (limited area treated and below ground) (Babendreier et al. 2015), it is also unlikely that applications of higher concentrations of azadirachtin are environmentally problematic (Boeke et al. 2004). This is also underlined by the biodegradable nature of azadirachtin. Interestingly our experiments showed a slight positive effect of higher doses of neem-granules on plant height and biomass in comparison to similarly effective chemical treatments. Although Xie et al. (1991) did not observe such effects, it may potentially confirm the biofertilizer properties of neem in maize as suggested by Vageesh et al.(2016).

\section{Conclusion}

In conclusion, there seems clear potential for the development of a neem-based botanical soil insecticide if the required higher concentrations of azadirachtin in the granule, or potentially fluid formulation can be achieved. The currently suggested standard dosage of $38 \mathrm{~g}$ azadirachtin/hectare corresponds to $25 \mathrm{~kg}$ granules/hectare. Many commercial applicators for fine granules on sowing machines may deliver not more than $20 \mathrm{~kg}$ hectare. Therefore, a higher concentration of azadirachtin in less weight of granules would be needed if the application for rootworm control at larger field scale was to become reality. In a next step, larger open field trials using farmer machinery are suggested towards the development of a practical and effective neem-based soil insecticide for corn rootworm control in maize. Those, experiments should clarify whether for example $50,200,380 \mathrm{~g}$ or more azadirachtin would be needed/hectare under real farming conditions to suppress $D$. v. virgifera larval populations below threshold and to sufficiently prevent root damage to avoid yield losses. If this is achieved, such product(s) may become a promising, safer alternative in the management of rootworms such as $D$. v. virgifera and potentially other soil insect pests. This could become a replacement of some of the banned soil insecticides or insecticidal seed coatings, and will ultimately help diversify the currently limited integrated pest management toolbox.

\section{Supplementary Information}

The online version contains supplementary material available at https://doi. org/10.1186/s43170-021-00044-9.

Additional file 1. Dose-efficacy response of azadirachtin in killing neonates of Diabrotica v. virgifera in artificial diet-based bioassays of 96-well plates under standardised semi-sterile laboratory conditions.

\section{Acknowledgements}

This work was possible due to the hospitality of the Plant Protection and Soil Conservation Department of governmental offices of Csongrad-Csanad County in Hodmezovasarhely in Hungary, offered by Zoltán Borcsik, Aranka Beséné Kormány, Andrea Kun, and others. We like to thank Pete Clark and Erin Boland from Genective, Weldon, IL, USA as well as Virginie Guyon from Biogemma, Clermont-Ferrand in France for advice on artificial diet bioassays for rootworms. We like to thank Chad Nielson from USDA ARS Brookings, USA for providing the initial eggs of the non-diapause colony of D. v. virgifera 
for establishing a laboratory rearing. We like to thank Coromandel International Limited for providing neem granules for the experiments. For helpful comments on the use of azadirachtin in insect pest control, we gratefully acknowledge Pratik Doshi (SZIE University, Godollo). We like to thank the summer students Gift Nxumalo (SZIE University, Godollo) and Tamnna Chambyal (University of Szeged, Hungary) for help in experimental work.

\section{Authors' contributions}

All authors have substantially contributed to conception and design, analysis and interpretation of data, as well as to drafting and revising the article. All approved the final version to be published and agreed to be accountable for all aspects of the work. In addition to above, SzT and ST implemented the experiments and collected the data, MSz and ST conducted the statistical analyses, and ST supervised the study and finalised the manuscript. All authors read and approved the final manuscript.

\section{Funding}

$C A B I$ is grateful core funding from respective tax papers behind the European Commission, Department for International Development (DFID) of the UK, the Swiss Agency for Development and Cooperation (SDC), the Directorate General for International Cooperation (DGIS) of the Netherlands, Irish Aid International Fund for Agricultural Development, and the Australian Centre for International Agricultural Research. Szabolcs Toth was funded was funded through a Hungarian Governmental Ph.D. Scholarship and the Hungarian Higher Education Institutional Excellence Program (20430-3/2018/FEKUTSTRAT) of the Ministry of Human Capacities and the National Excellence Program of the Ministry for Innovation and Technology under the National Research, Development and Innovation Fund (ÚNKP-20-3-II-SZIE-44) as well as through the Ministry for Innovation and Technology within the framework of the Higher Education Institutional Excellence Program (NKFIH-1159-6/2019) in the scope of plant breeding and plant protection researches of Szent István University (TKP2020-IKA-12) and the EFOP-3.6.3-VEKOP-16-2017-00008 project co-financed by the European Union and the European Social Fund

\section{Availability of data and materials}

Meta-data are available in an additional file to the publication. Raw data are deposited in Zenodo (https://doi.org/10.5281/zenodo.4318642). Any other information is available upon request to the corresponding author.

\section{Declarations}

\section{Ethics approval and consent to participate}

All applicable international, national, and/or institutional guidelines for the care and use of animals were followed. This article does not contain any studies with human participants or vertebrates performed by any of the authors. Informed consent was obtained from all individual participants included in the study.

\section{Consent for publication}

All authors agree with this publication.

\section{Competing interests}

The authors declared no conflicts of interest.

\section{Author details}

${ }^{1} \mathrm{CABI}$, Rue des Grillons 1, CH 2800 Delémont, Switzerland. ${ }^{2}$ Department of Integrated Pest Management, Plant Protection Institute, Szent Istvan University, Pater K. Street 1, H 2100 Godollo, Hungary.

Received: 16 December 2020 Accepted: 2 June 2021

Published online: 01 July 2021

\section{References}

Al-Sharook Z, Balan K, Jiang Y, Rembold H. Insect growth inhibitors from two tropical Meliaceae. Effect of crude seed extracts on mosquito larvae. J Appl Entomol. 1991;111:425-30.

Anonymous. EPPO Standards. Phytotoxicity assessment: efficacy evaluation of plant protection products. 1/135 (3). EPPO Bull. 2009;37:4-10.
Anonymous. Evaluation of insecticides: Diabrotica v. virgifera. EPPO PP 1/212(1), 1999. 3 pp.

Babendreier D, Jeanneret P, Pilz C, Toepfer S. Non-target effects of insecticides, entomopathogenic fungi and nematodes applied against western corn rootworm larvae in maize. J Appl Entomol. 2015;139(6):457-67.

Balaji S. An effective and efficient granular neem based bio-pesticide for pest management. IBMA conference, Basel, October 2014. 2014. https://www. abim.ch/fileadmin/abim/documents/presentations2014/2_S_Balaji_ ABIM2014.pdf.

Benjamini Y, Hochberg Y. Controlling the false discovery rate: a practical and powerful approach to multiple testing. J R Stat Soc. 1995;57:289-300.

Bhagat RM. Field evaluation of some insecticides against white grub in maize under mid-hill conditions of Himachal Pradesh. J Entomol Res. 2005;29:123-5.

Boeke M, Boersma G, Alink J, van Loon A, Dicke M. Safety evaluation of neem (Azadirachta indica) derived pesticides. J Ethnopharmacol. 2004;49:25.

Boiça Júnior AL, Costa EN, de Souza BHS, Ribeiro ZA, Costa ES, Forim MR. Neem extract formulations to control Diabrotica speciosa (Coleoptera: Chrysomelidae) larvae in maize. Rev Colomb Entomol. 2017;43:245-50.

Branson TF, Guss PL, Krysan JL, Sutter GR. Corn rootworms: laboratory rearing and manipulation, Agricultural research service-U.S.D.A. USDA ARS, Peoria. 1975.

Chiang HC. Bionomics of the northern and western corn rootworms. Annu Rev Entomol. 1973;18:47-72.

Clair CRS, Head GP, Gassmann AJ. Western corn rootworm abundance, injury to corn, and resistance to $C r y 3 B b 1$ in the local landscape of previous problem fields. PLoS ONE. 2020;15:e0237094.

CRC. The neem tree: focus on phytochemical pesticides. Boca Raton: CRC Press Inc; 1989.

Demeter E, Lazar MV. Növényvédő szerek értékesítése, 2019 (Sales of plant protection products in Hungary in 2019), XIX. évfolyam 1. szám. 2020. (in Hungarian).

Dent DR, Walton MP. Methods in ecological and agricultural entomology. Wallingford: CAB International; 1998.

Domínguez-Arrizabalaga M, Villanueva M, Escriche B, Ancín-Azpilicueta C, Caballero P. Insecticidal activity of Bacillus thuringiensis proteins against Coleopteran pests. Mdpitoxins. 2020;12:430.

Doshi P, Póss AM, Tóth F, Szalai M, Turóczi G. Effect of neem-derived plant protection products on the isopod species Porcellionides pruinosus. Zookeys. 2018;801:415-25.

Doshi P, Tóth F, Nagy P, Turóczi G, Petrikovszki R. Comparative study of two different neem-derived pesticides on Meloidogyne incognita under in vitro and pot trials under glasshouse conditions. Columella-J Agric Environ Sci. 2020;7:11-22.

Dougoud J, Toepfer S, Bateman M, Jenner W. Efficacy of homemade botanical insecticides based on traditional knowledge. A review. Agron Sustain Dev. 2019;39:1-22.

Dulmage T, Yousten AA, Singer S, Lacey LA, Guidelines for the production of Bacillus thuringiensis $\mathrm{H}-14$ and Bacillus sphaericus. UNDP/WHO/WHO special programme for research and training in tropical diseases. 1990. TDR/BCV/90.1. 15.

Estes K, Kleczewski N, Ames K, Seiter N. Applied research results on field crop pest and disease control. USA. 2018.

European Commission. Establishing a framework for community action to achieve the sustainable use of pesticides. Directive 2009/128/EC of the European parliament and council. Off J Eur Union L 309/71. 2009. 16 pp.

European-Commission. Commission implementing regulation (EU) No 800/2011 approving the active substance tefluthrin, in accordance with Regulation (EC) No 1107/2009 of the European Parliament and of the Council concerning the placing of plant protection products on the market. Off J Eur Union L. 2011;205:22-6.

Fan X. The vice minister's speech in the national working conference of plant protection. China Plant Prot. 2006;26:5-13.

Gassmann AJ, Shrestha RB, Kropf AL, St Clair CR, Brenizer BD. Field-evolved resistance by western corn rootworm to Cry34/35Ab1 and other Bacillus thuringiensis traits in transgenic maize. Pest Manag Sci. 2020;76:268-76.

George BW, Ortman EE. Rearing the western corn rootworm in the laboratory. J Econ Entomol. 1965;58:375-7.

Georgiadis PT, Pistorius J, Heimbach U. Dust in the wind-drift of dust containing insecticides - a risk for honey bees (Apis mellifera)? Julius-KühnArchiv. 2011;430:15-9. 
Hills TM, Peters DC. A method of evaluating postplanting insecticide treatments for control of western corn rootworm larvae. J Econ Entomol. $1971 ; 64: 764-5$

Huynh MP, Meihls LN, Hibbard BE, Lapointe SL, Niedz RP, Ludwick DC. Diet improvement for western corn rootworm, Diabrotica virgifera virgifera, larvae without corn root powder. PLoS ONE. 2018;12(11):e0187997.

Huynh MP, Hibbard BE, Vella M, Lapointe SL, Niedz RP, Shelby KS, Coudron TA. Development of an improved and accessible diet for western corn rootworm larvae using response surface modeling. Sci Rep. 2019;9:16009.

Kim KS, Sappington TW. Genetic structuring of western corn rootworm (Coleoptera: Chrysomelidae) populations in the United States based on microsatellite loci analysis. Environ Entomol. 2005;34:494-503.

Kinnear PR, Gray CD. SPSS for windows made simple. East Sussex: Psychology Press Ltd; 2000.

Krysan JL, Miller TA. Methods for the study of pest Diabrotica. London: Springer; 1986. p. 260.

Ladd TL Jr, Warthen JD Jr, Klein MG. Japanese beetle (Coleoptera: Scarabaeidae): the effects of azadirachtin on the growth and development of the immature forms. J Econ Entomol. 1984;77:903-5.

Landis DA, Gould F. Investigating the effectiveness of feeding deterrents against the southern corn rootworm, using behavioral bioassays and toxicity testing. Entomol Exp Appl. 1989;51:163-74.

Levine E, Oloumi-Sadeghi H. Management of diabroticite rootworms in corn. Annu Rev Entomol. 1991:36:229-55.

Magalhaes LC, French BW, Hunt TE, Siegfried BD. Baseline susceptibility of western corn rootworm (Coleoptera: Chrysomelidae) to clothianidin. J Appl Entomol. 2007;131:251-5.

Mehaoua MS, Hadjeb A, Lagha M, Bensalah MK, Ouakid ML. Study of the toxicity of azadirachtin on larval mortality and fertility of carob moth's female (Lepidoptera, Pyralidae) under controlled conditions. Am J Sustain Agric. 2013;7:1-9.

Merabti B, Lebouz I, Ouakid ML. Larvicidal activity and influence of azadirachtin (neem tree extract) on the longevity and fecundity of mosquito species. Acta Zool Bulg. 2017;69:429-35.

Miller N, Estoup A, Toepfer S, Bourguet D, Lapchin L, Derridj S, Kim KS, Reynaud P, Furlan L, Guillemaud T. Multiple transatlantic introductions of the western corn rootworm. Sci. 2005;310:992.

MoA. Instruction of general office of Ministry of Agriculture of the People's Republic of China (MoA) on facilitating Green Pest Control of Crop Pests. 2011. http://www.moa.gov.cn/zwllm/tzgg/tz/201105/t20110523_19961 35.htm.

Moar W, Khajuria C, Pleau M, Ilagan O, Chen M, Jiang C, Price P, McNulty B, Clark T, Head G. Cry3Bb1-resistant western corn rootworm, Diabrotica virgifera virgifera does not exhibit cross-resistance to DvSnf7 dsRNA. PLOS ONE. 2017;12(1):e0169175.

Modic Š, Žigon P, Kolmanič A, Godeša T, Razinger J. Effectiveness of different control measures against western corn rootworm larvae Diabrotica virgifera virgifera. Acta Agric Slov. 2018;111:161-7.

Oleson JD, Park YL, Nowatzki TM, Tollefson JJ. Node-injury scale to evaluate root injury by corn rootworms (Coleoptera: Chrysomelidae). J Econ Entomol. 2005;98:1-8

Pilz C, Keller S, Kulhmann U. Comparative efficacy assessment of fungi, nematodes and insecticides to control western corn rootworm larvae in maize. Biocontrol. 2009;54:671-84.

Pleau MJ, Huesing JE, Head GP, Feir DJ. Development of an artificial diet for the western corn rootworm. Entomol Exp Appl. 2002;105:1-11.
Qadri SSH, Narsaiah J. Effect of azadirachtin on the moulting processes of last instar nymphs of Periplaneta americana. Indian J Exp Biol. 1978;16:1141-3.

R Development Core Team. R: a language and environment for computing Vienna: R Foundation for Statistical Computing; 2020.

Reed DK, Warthen JD, Uebel EC, Reed GL. Effects of two triterpenoids from neem onfeeding by cucumber beetles (Coleoptera: Chrysomelidae). J Econ Entomol. 1982;75:1109-13.

Saxena RC. Insecticides from neem. In: Arnason JT, Philogène BJR, Morand P, editors. Insecticides of plant origin. Washington, DC: American Chemical Society; 1989. p. 110-35.

Scmutterer $\mathrm{H}$. The neem tree: Azadirachta indica and other meliaceous plants. Weinheim: Wiley Online Library; 1995

Singh P, Moore RF. Handbook of insect rearing. Amsterdam: Elsevier; 1999.

Souza D, Peterson JA, Wright R, Meinke L, Wright RJ, Meinke LJ. Field efficacy of soil insecticides on pyrethroid-resistant western corn rootworms (Diabrotica virgifera virgifera). Pest Manag Sci. 2020;76:827-33.

Sowley ENK, Ofori RA, Kankam F. Evaluation of neem (Azadirachta indica) seed and Cassia alata leaf extracts as surface protectants against seed borne fungi of maize (Zea mays). Pak J Phytopathol. 2017;29:1-5.

Stark JD, Rangus TM. Lethal and sublethal effects of the neem insecticide formulation, 'Margosan-O', on the pea aphid. Pestic Sci. 1994;41:155-60.

Stark JD, Walter JF. Neem oil and neem oil components affect the efficacy of commercial neem insecticides. J Agric Food Chem. 1995;43:507-12.

Sutter GR, Krysan JL, Guss PL. Rearing the southern corn rootworm on artificial diet. J Econ Entomol. 1971;64:65-7.

Toepfer S, Hatala-Zseller I, Ehlers RU, Peters A, Kuhlmann U. The effect of application techniques on field-scale efficacy: can the use of entomopathogenic nematodes reduce damage by western corn rootworm larvae? Agric for Entomol. 2010;12:389-402.

Toepfer S, Li H, Pak SG, Son KM, Ryang YS, II KS, Han R, Holmes K. Soil insect pests of cold temperate zones of East Asia, including DPR Korea: a review. J Pest Sci. 2014;87:567-95.

Toth S, Szalai M, Kiss J, Toepfer S. Missing temporal effects of soil insecticides and entomopathogenic nematodes in reducing the maize pest Diabrotica virgifera virgifera. J Pest Sci. 2020;93:767-81.

Vageesh TS, Sanjaykumar W, Abhiram GJ, Girijesh GK. Growth and yield of maize as influenced by compost enriched with NPK fertilizers and neem oil coated urea under rainfed conditions. Environ Ecol. 2016;34:824-7.

van Rozen K, Ester A. Chemical control of Diabrotica virgifera virgifera. J Appl Entomol. 2010;134:376-84.

World Health Organization. WHO recommended classification of pesticides by hazard, International Programme on Chemical Safety II. 2009.

Wright RJ, Scharf ME, Meinke LJ, Zhou XG, Siegfried BD, Chandler LD. Larval susceptibility of an insecticide-resistant western corn rootworm (Coleoptera: Chrysomelidae) population to soil insecticides: laboratory bioassays, assays of detoxification enzymes, and field performance. J Econ Entomol. 2000;93:7-13.

Xie YS, Gagnon D, Arnason JT, Philogene BJR, Lambert JDH, Kaminski J, Morand P, Timmins G, Werstiuk NH. Effects of azadirachtin on the western corn rootworm, Diabrotica virgifera virgifera (Coleoptera: Chrysomelidae). Can Entomol. 1991;123:707-10.

\section{Publisher's Note}

Springer Nature remains neutral with regard to jurisdictional claims in published maps and institutional affiliations. 